\title{
GENERAL GROUP VI TRANSITION NANOSTRUCTURED METAL OXIDES AND THEIR INCLUSION INTO SOLID MATRICES BY A SOLUTION-SOLID APPROACH
}

\author{
C. DÍAZ ${ }^{1 *}$, M.L. VALENZUELA ${ }^{2 *}$, LILIA ZEPEDA ${ }^{1}$, PABLO HERRERA ${ }^{1}$ AND CONSTANZA VALENZUELA ${ }^{1}$ \\ ${ }^{\text {I}}$ Departamento de Química, Facultad de Química, Universidad de Chile, La Palmeras 3425, Nuñoa, casilla 653, Santiago de Chile, Chile. \\ ${ }^{2}$ Instituto de Ciencias Químicas Aplicadas, Grupo de Investigación en Energía y Procesos Sustentables, Facultad de Ingeniería, Universidad Autónoma de Chile, \\ Av. El Llano Subercaseaux 2801, San Miguel, Santiago de Chile, Chile.
}

\begin{abstract}
A facile and general solution//solid-state (SSS) approach to the synthesis of nanostructured metal oxides $\mathrm{Cr}_{2} \mathrm{O}_{3}, \mathrm{MoO}_{3}$ and $\mathrm{WO}_{3}$ was investigated. They are made

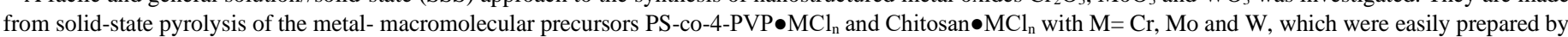
direct reaction of the salts $\mathrm{CrCl}_{3}, \mathrm{MoCl}_{4}$ and $\mathrm{WCl}_{4}$ with the respective polymer. The size and morphology of the products, the nanostructured oxides $\mathrm{Cr}_{2} \mathrm{O}_{3}, \mathrm{MoO}_{3}$ and $\mathrm{WO}_{3}$ depend on the polymer and on the coordination degree of the precursor. $\mathrm{Cr}_{2} \mathrm{O}_{3}$ as well as $\mathrm{WO}_{3}$, prepared from this method were included in silica and Titania matrix using an also solution//solid-state approximation. The nanoparticles of $\mathrm{Cr}_{2} \mathrm{O}_{3}$ and $\mathrm{WO}_{3}$ are in general distributed with uniformity within the amorphous silica. A probable formation mechanism of the $\mathrm{Cr}_{2} \mathrm{O}_{3}, \mathrm{MoO}_{3}$ and $\mathrm{WO}_{3}$ nanoparticles was proposed. The nanocomposites $\mathrm{Cr}_{2} \mathrm{O}_{3} / / \mathrm{SiO}_{2}$ and $\mathrm{WO}_{3} / / \mathrm{SiO}_{2}$ could be useful materials in catalysis.
\end{abstract}

Keywords: Solid-state, pyrolysis, nanostructured, metal oxide

\section{INTRODUCTION}

Among the metal-ligand coordination compounds, the macromolecular complexes [1] can be considered as a special case, where the ligand has multiple coordination sites. The preparation of such metal multi-sites ligands is usually difficult because of metal ions must coordinate hundreds and sometimes thousands of coordination sites. This process is often of a slow kinetics, being the products usually insoluble and of poor characterization. Thus, these macromolecular complexes rarely reach the $100 \%$-degree coordination [2-5]. In spite of this, this particular type of multi-coordination compounds have attracted much the attention due to their interesting applications in the materials science. For instance the metallic derivate from polyphosphazenes affords, after pyrolysis at $800{ }^{\circ} \mathrm{C}$ under air, nanostructured materials of the type $\mathrm{M}^{\circ}$ and $\mathrm{M}_{\mathrm{x}} \mathrm{O}_{\mathrm{y}} / \mathrm{M}_{\mathrm{x}}\left(\mathrm{PO}_{\mathrm{Y}}\right) \mathrm{z}$ [6-9].The metallic phosphate phases normally appears due to the presence of phosphorus atoms in the polymeric chain.

Metal oxides have attracted great interest for their applications as anode materials for lithium batteries [10,11], catalysis [12,13], sensors [14], solar cells [15], solid-state transistors [16] and metal ion removal [17]. Although several solution methods to prepare metal oxides have been reported [18-22] few solidstate routes have appeared $[23,24]$. The aim of developing solid-state methods to prepare nanoparticles stems mainly from their possible application in solid-state materials and powder-oriented applications, from thin film metal deposition to noble metal nanoparticle-carbon catalysts, oxide growth, photonic and dielectric materials, to new materials for $\mathrm{Li}$-ion rechargeable batteries. The ability to rationally prepare metallic and metal oxide nanoparticles stems from the exploring methods for alternative nanoscale metal deposition in solid-state nanoelectronics and nanotechnology [25-28] and the benefit of being able to deposit both metals and dielectric or semiconducting oxides, both from the same base route. Issues including limitations on good mechanical and thermal stability of nanoscale metal have been found related to certain deposition methods for these metals. Most of this application requires pure phase metal oxides.

For group VI metal oxide there not a general method to prepare these nanostructured materials. For instance, using $\mathrm{W}(\mathrm{CO})_{6}$ as precursors the $\mathrm{W}_{18} \mathrm{O}_{49}$ nanostructured molibdenum oxide was obtained [29]. On the other hand the $\mathrm{Cr}_{2} \mathrm{O}_{3}$ nanostructured nanoparticles was obtained from the thermal treatment of the carbene Fischer $(\mathrm{CO})_{5} \mathrm{CrC}(\mathrm{Ph})(\mathrm{OMe})$ [30].The nanostructured $\mathrm{MoO}_{3}$ was obtained from a hydrothermal method using $\left(\mathrm{NH}_{4}\right)_{6} \mathrm{Mo}_{7} \mathrm{O}_{24} \bullet 4 \mathrm{H}_{2} \mathrm{O}$ as source of Mo [31]. Alternatively other methods have also been used to obtain the nanostructured $\mathrm{Cr}_{2} \mathrm{O}_{3}, \mathrm{MoO}_{3}$ and $\mathrm{WO}_{3}$ [32-38]. On the other hand, the thermal treatment $\left\{\left[\mathrm{NP}\left(\mathrm{O}_{2} \mathrm{C}_{12} \mathrm{H}_{8}\right)\right]_{0.8}\left[\mathrm{NP}\left(\mathrm{OC}_{6} \mathrm{H}_{4} \mathrm{CH}_{2} \mathrm{CN} \bullet\left[\mathrm{Cr}(\mathrm{CO})_{5}\right]_{0.13}\right)_{2}\right]_{0.18}\right\}_{n}$ results in the formation of nanometer-size metal oxide particles [38]

We have developed a new solid-state method to prepare phase pure metal oxide nanoparticles from the macromolecular complexes Chitosan $\bullet \mathrm{MXn}$ and $\mathrm{PS}-\mathrm{co}-4-\mathrm{PVP} \bullet \mathrm{MXn}$ (PS-co-4-PVP = Poly(styrene-co-4-vinylpyridine) $)$ see scheme 1. In this paper the phase pure $\mathrm{Cr}_{2} \mathrm{O}_{3}, \mathrm{MoO}_{3}$ and $\mathrm{WO}_{3}$ were prepared using this synthetic approach. We have chosen Chitosan because of it is a cheap commercial product and by their effective coordinative properties to ion metal. Chitosan [39-41] is a polysaccharide obtained by deacetylation of natural chitin, which is one of the important natural polymers constituting the shells of crustaceans and the cell wall of many fungi. Due to its available from the $\mathrm{NH}_{2}$ groups and the $\mathrm{OH}$ moieties present in the polysaccharide chains; it can bind metal ions -in solution- forming macromolecular metal complexes [42-44]. Although the ability to retain metal ions in solution, Chitosan has been widely studied and previously reported, solid-state-macromolecular complexes have been not well characterized. Particularly for several some $\mathrm{Cu} /$ Chitosan complexes, some X-ray and ESR studies have been performed [45-47]. Chitosan can act as solution template/stabilizer for the formation of nanoparticles [47-55]. Some biological applications [54-55] including biosensors for glucose have been reported [58]. In addition, Chitosan as support for catalysis processes have been also described [56].

On the other hand, Poly(styrene-co-4vinylpyridine) is useful functional copolymer due to the vinylpyridine block which binds metal ions and the styrene groups to facilitate stable macromolecular complexes 1, [53-56]. It has also been used to aid in selective facet growth in noble metal nanoparticle. PS- $b-4-P V P$ has been used in solution as a template/stabilizer of metals and other nanoparticles [57-60]

Although several solution methods to prepare nanostructured $\mathrm{Cr}_{2} \mathrm{O}_{3}, \mathrm{MoO}_{3}$ and $\mathrm{WO}_{3}$ oxides few solid-state routes have been informed [61-67]. Using a solid state approach with precursors having the organometallic fragment $\mathrm{W}(\mathrm{CO})_{5}$ linked to oligo and poly-phosphazene mixtures of $\mathrm{W} / \mathrm{WO}_{3} / \mathrm{WP}_{2} \mathrm{O}_{3}$ mixtures are obtained [68] while that using the organometallic derivatives of poly(styrene-co4vinylpyridine), $\left.\left[\mathrm{CH}_{2} \mathrm{CH}\left(\mathrm{C}_{6} \mathrm{H}_{5}\right)\right]_{0.1}\left[\mathrm{CH}_{2} \mathrm{CH}\left(\mathrm{C}_{5} \mathrm{H}_{4} \mathrm{~N} \bullet \mathrm{ML}_{\mathrm{n}}\right)\right]_{0.9}\right\}_{\mathrm{n}} ; \mathrm{ML}_{\mathrm{n}}=\mathrm{W}(\mathrm{CO})_{5}$ ,as precursors pure $\mathrm{WO}_{3}$ obtained [69] . On the other hand from the $\mathrm{N}_{3} \mathrm{P}_{3}\left[\mathrm{OC}_{6} \mathrm{H}_{4} \mathrm{CH}_{2} \mathrm{CN} \cdot \mathrm{Mo}(\mathrm{CO})_{5}\right]_{6}$ (I) and $\mathrm{N}_{3} \mathrm{P}_{3}\left[\mathrm{OC}_{6} \mathrm{H}_{4} \mathrm{CH}_{2} \mathrm{CN} \cdot \mathrm{Mo}(\mathrm{CO})_{5}\right]_{6}$ (II) precursors pure phase $\mathrm{MoO}_{3}$ was obtained [69]. 


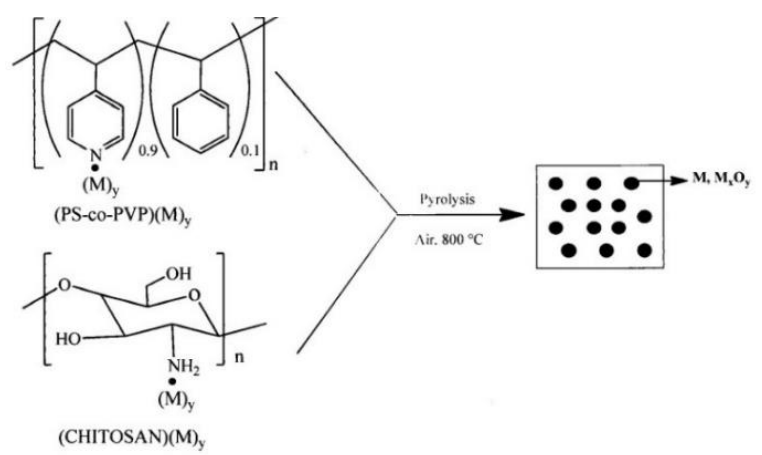

Figure 1. Schematic representation of the PS-co-4-PVP•MXn and Chitosan $\bullet$ MXn precursors.

The scheme shows the $\mathrm{M}-\mathrm{N}$ (pyridine) and $\mathrm{M}-\mathrm{NH}_{2}$ coordination site but not the structure of the metal-polymer complexes. Here $\mathrm{M}$ represent the respective metallic salt linked to the polymeric chain i.e. $\mathrm{CrCl}_{3}, \mathrm{MoCl}_{4}$ and $\mathrm{WCl}_{4}$

Here we present a general and reliable solid-state method for to obtain the respective metal oxide nanoparticles $\mathrm{Cr}_{2} \mathrm{O}_{3}, \mathrm{MoO}_{3}$ and $\mathrm{WO}_{3}$ from the PS-co-4$\mathrm{PVP} \bullet \mathrm{MXn}$ and Chitosan $\bullet \mathrm{MXn}$ precursors and also useful for their inclusion into solid matrix $\mathrm{SiO}_{2}$.

\section{EXPERIMENTAL}

\section{Materials and Common Procedures}

$\mathrm{CrCl}_{3} \cdot 2 \mathrm{H}_{2} \mathrm{O}, \mathrm{MoCl}_{4}$ and $\mathrm{WCl}_{4}$, from Aldrich were used as received. Chitosan (Aldrich) of low molecular weight was used as receive. An estimation of the molecular weight was performed by viscosimetry. The average molecular weight was determined from the Mark-Houwink equation and values of $[\mathrm{h}]$ obtained using parameter previously reported by Rinaudo et al [47]. The solvent used was a aqueous solution of acetic acid, $\mathrm{NaCl}$ and urea. The value was $\mathrm{Mw}=61.000$. All the reactions were performed in $\mathrm{CH}_{2} \mathrm{Cl}_{2}$ as solvent. Poly(styrene-co-4vinylpyridine) Aldrich with a $90 \%$ of pyridine groups was used as received.

\section{General Procedure}

Metal-macromolecular complexes (1), (2) and (3) were prepared according to published procedures [69-71]. In a typical synthesis, the respective metallic salt was added in a Schlenk tube over a $\mathrm{CH}_{2} \mathrm{Cl}_{2}$ solvent under magnetic stirring and then the respective polymer PSP-co-4-PVP or Chitosan was added amount according to a 1:1, molar ratio. Reaction time and other details for each metallic salts reaction are given in Table 1 of Supplementary Materials. After this, the supernatant solution (if the solid decanted) was extracted with a syringe and the solid was dried under reduced pressure. Experimental details for the reactions are given in table see Table 1 of Supplementary data S1. The precursor PS-co-4$\mathrm{PVP} \bullet \mathrm{CrCl}_{3} / / \mathrm{SiO}_{2}$ and Chitosan $\bullet \mathrm{CrCl}_{3} / / \mathrm{SiO}_{2}$ and PS-co-4-PVP• $\mathrm{WCl}_{4} / / \mathrm{SiO}_{2}$, Chitosan $\bullet \mathrm{WCl}_{4} / / \mathrm{SiO}_{2}$ were prepared incorporating to the reaction, TEOS for generating $\mathrm{SiO}_{2}$ [71].Experimental details are given in Table 1 of Supplementary Materials.

\section{Characterization of the precursors}

Owing their insolubility characterization of the precursors was made only by, IR spectroscopy.

\section{Pyrolysis of the precursors}

The pyrolysis experiments were made by pouring a weighed portion $(0.05-$ $0.15 \mathrm{~g}$ ) of the metal-polymer precursor 1-6 into aluminum oxide boats that were placed in a furnace (Daihan oven model Wise Therm FHP-12) under a flow of air, heating from $25^{\circ} \mathrm{C}$ to upper temperature limits of $300^{\circ} \mathrm{C}$, and then to $800{ }^{\circ} \mathrm{C}$, followed by annealing for $2-4 \mathrm{~h}$ in each case. The heating rate was consistently maintained at $10{ }^{\circ} \mathrm{C} \mathrm{min}^{-1}$ for all experiments. Solid pyrolytic samples were characterized by X-Ray diffraction of powders (XRD) scanning electron microscopy (SEM), high resolution transmission electron microscopy (HRTEM), Fourier transform infra-red (FTIR) spectroscopy, and thermogravimetric (TG) and differential scanning calorimetric (DSC) analysis.
SEM images were acquired with a Philips EM 300 scanning electron microscope. Energy dispersive X-ray analysis (EDAX) was performed on a NORAN Instrument micro-probe attached to a JEOL 5410 scanning electron microscope. Transmission electron microscopy (TEM) experiments were performed using a FEI Tecnai T20 microscope, operated at $200 \mathrm{kV}$, in order to analyses the average size, distribution and morphology of the particles. High-resolution transmission electron microscopy (HRTEM) was performed using a JEOL 2000FX microscope at $200 \mathrm{kV}$. Interplanar distances were measured using the Gatan Digital Micrograph software. The TEM samples were prepared by dispersing pyrolized material onto copper grids, previously sonicated under ethanol media and then dried at room temperature. For high-resolution examination of graphitic carbons, flakes of sonicated carbons were dispersed on grids and examined under SEM to determine their thickness. X-ray diffraction (XRD) was conducted at room temperature on a Siemens D-5000 diffractometer with $\theta-2 \theta$ geometry. The XRD data was collected using $\mathrm{Cu}-\mathrm{K} \alpha$ radiation $(40 \mathrm{kV}, 30 \mathrm{~mA})$. FTIR measurements were performed on a Perkin Elmer FTIR spectrophotometer model Spectrum BXII.

\section{RESULTS AND DISCUSSION}

\section{Macromolecular complexes}

The direct reaction of the metallic salts $\mathrm{CrCl}_{3}, \mathrm{MoCl}_{4}$ and $\mathrm{WCl}_{3}$ with the respective polymer Chitosan or PSP-co-4-PVP in $\mathrm{CH}_{2} \mathrm{Cl}_{2}$ as solvent affords very stable insoluble solids with colors stem from the coordination of the metal ion to the polymer. For instance precursors, green from the (Chitosan) $\left(\mathrm{CrCl}_{3}\right)_{\times}$ and PS-co-4-PVP• $\left(\mathrm{CrCl}_{3}\right)_{\mathrm{x}}$ see $\mathrm{S}_{1}$ Supplementary data.

Coordination of the metal ions to the coordinating groups of both polymers was achieved by IR spectroscopy. For Chitosan-metal complexes the coordination was evident from the broad $v(\mathrm{OH})$ in Chitosan $[44,46,70]$ which becomes unfolded upon coordination, appearing a new band around $3100 \mathrm{~cm}^{-1}$. On the other hand for poly(styrene-co-4-vinylpyridine) the coordination was confirmed by the emergence of a new band centered at $1600 \mathrm{~cm}^{-1}$ characteristic of pyridine coordination [69,70]. Selected data for the precursor PS-co-4-PVP• $\left(\mathrm{MoCl}_{4}\right)_{\mathrm{n}}$ and Chitosan $\bullet\left(\mathrm{MoCl}_{4}\right)_{\mathrm{n}}$ are shows in Supplementary data, S2.

\section{Pyrolysis of Macromolecular complexes}

The pyrolytic products were characterized by XRD powers. Illustrative XDR the pyrolytic products $\mathrm{Cr}_{2} \mathrm{O}_{3}, \mathrm{MoO}_{3}$ and $\mathrm{WO}_{3}$ from the respective precursors PS-co-4-PVP $\bullet \mathrm{MXn}$ are shown in supplementary data S3, figure A. For precursors (2) sharp peaks -among other less intense-were obtained at corresponding to the planes (012), (104), (110), (113), (024) and (116) indicate the rhombohedra $\mathrm{Cr}_{2} \mathrm{O}_{3}$ [32]. Fig. B of $\mathrm{S} 3$ shows the XRD peaks which can be indexed to orthorhombic crystal $\mathrm{MoO}_{3}$ (JCPDS card $\mathrm{N}^{\circ}$ 00-005-0508). Main peak was observed at (020), (110), (040) (021) (111), (112), (060), see Fig S3. Thus the crystal phase is somewhat different to that obtained from precursors $\mathrm{N}_{3} \mathrm{P}_{3}\left[\mathrm{OC}_{6} \mathrm{H}_{4} \mathrm{CH}_{2} \mathrm{CN} \cdot \mathrm{Mo}(\mathrm{CO})_{5}\right]_{6}$ (I) and $\mathrm{N}_{3} \mathrm{P}_{3}\left[\mathrm{OC}_{6} \mathrm{H}_{4} \mathrm{CH}_{2} \mathrm{CN} \cdot \mathrm{Mo}(\mathrm{CO})_{5}\right]_{6}$ (II) precursors [69] were some fraction of lamellar was also observed. The observed XRD pattern is similar to that of $\mathrm{MoO}_{3}$ obtained by another solution method. [33].

Figure $\mathrm{C}$ of $\mathrm{S} 3$ shows the XRD peaks which can be indexed to monoclinic crystal $\mathrm{WO}_{3}$ (JCPDS card No ${ }^{\text {ro }}$ 01-083-0950). Main peak was observed at (002), (020), (200) (120) (-120), (112), (022), (220) (-202) and (400) see Fig S3. The observed XRD pattern is similar to that of pyrolytic residue from the organometallic precursors $\left[\mathrm{CH}_{2} \mathrm{CH}\left(\mathrm{C}_{6} \mathrm{H}_{5}\right)\right]_{0.1}\left[\mathrm{CH}_{2} \mathrm{CH}\left(\mathrm{C}_{5} \mathrm{H}_{4} \mathrm{~N} \bullet\left(\mathrm{W}(\mathrm{CO})_{5}\right)\right]_{0.9}\right\}_{n}$ [68].

As is usually observed for nanoparticles produced by thermal methods the size and shapes exhibits wide distributions being usually rather big sizes and with a variety of shapes [23]. TEM images for the Cr precursors show a clear dependence of the size with the molar ratio as shown in figure 2 . There is no clear explanation for this finding, although it could be related with the form of how the metallic centers are distributed along the polymeric chain. HRTEM images show different morphologies for the pyrolytic products from the chromium oxide. Figure 2 (f) confirmed the formation of $\mathrm{Cr}_{2} \mathrm{O}_{3}$, as the interplanar distance of $0.25 \mathrm{~nm}$ (110) was measured. EDS analysis see figure $2 \mathrm{~d}$ shows as expected the presence of $\mathrm{Cr}$ and $\mathrm{O}$ (also $\mathrm{Cu}$ arising from the copper grid). 

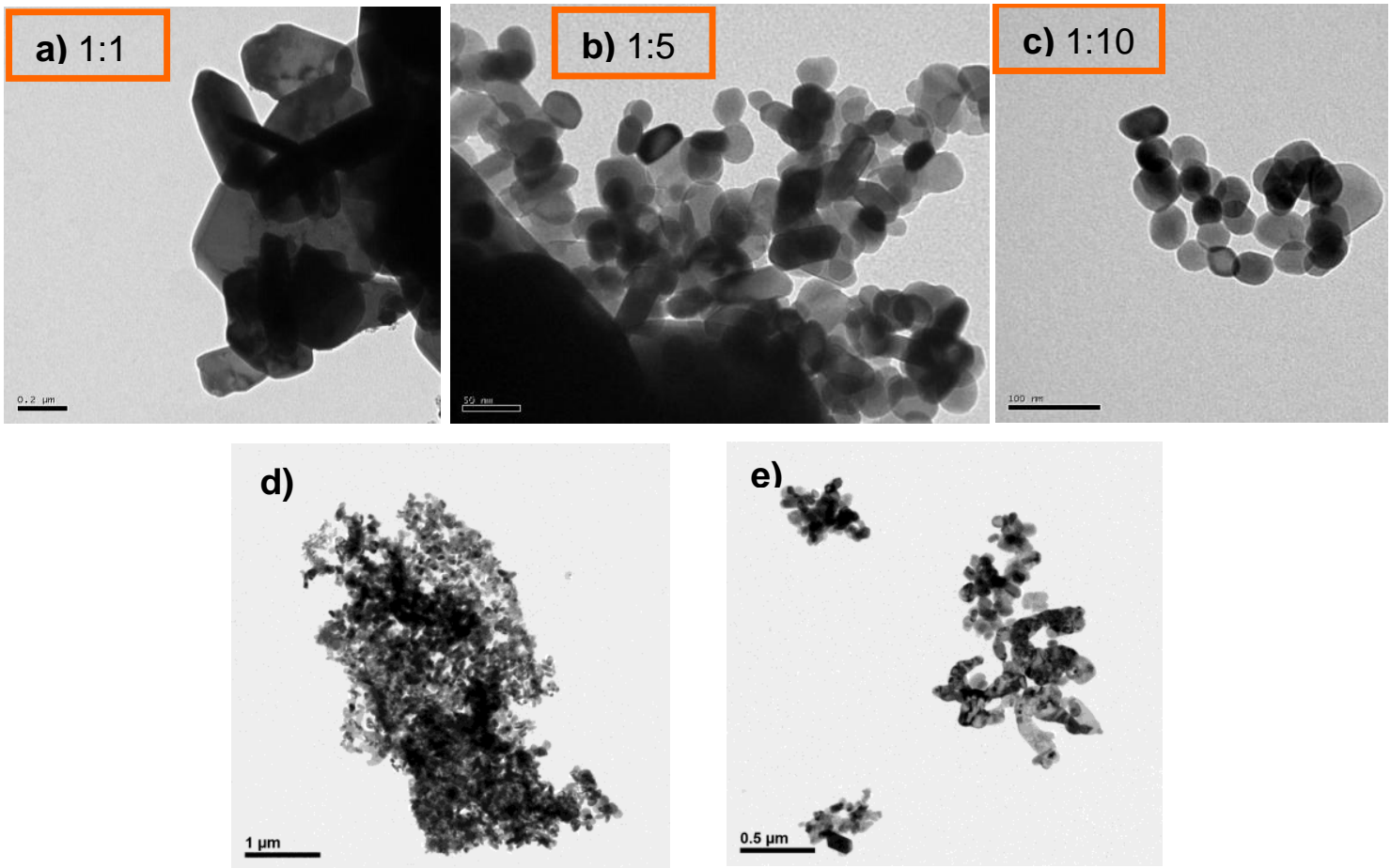

Figure 2.TEM a), b), c) HRTEM d), e) and EDS g) of $\mathrm{Cr}_{2} \mathrm{O}_{3}$.

On the other hand, the TEM image shows a no relationship of the size with the molar ratios for the Mo precursors. For the pyrolytic product from the precursors 1:1 Chitosan $\bullet \mathrm{MoCl}_{3}$, somewhat big bars nanostructures were observed see figure 3 . The SAED image, figure $3 \mathrm{~d}$, exhibits the presence of some planes characteristic

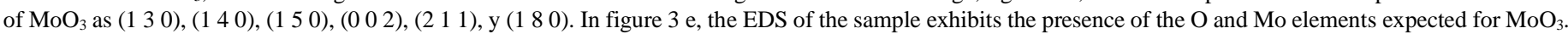
HRTEM image (figure 3d) confirmed the structure of $\mathrm{WO}_{3}$. The inset shows a SAE of the area with the zone axis [010].
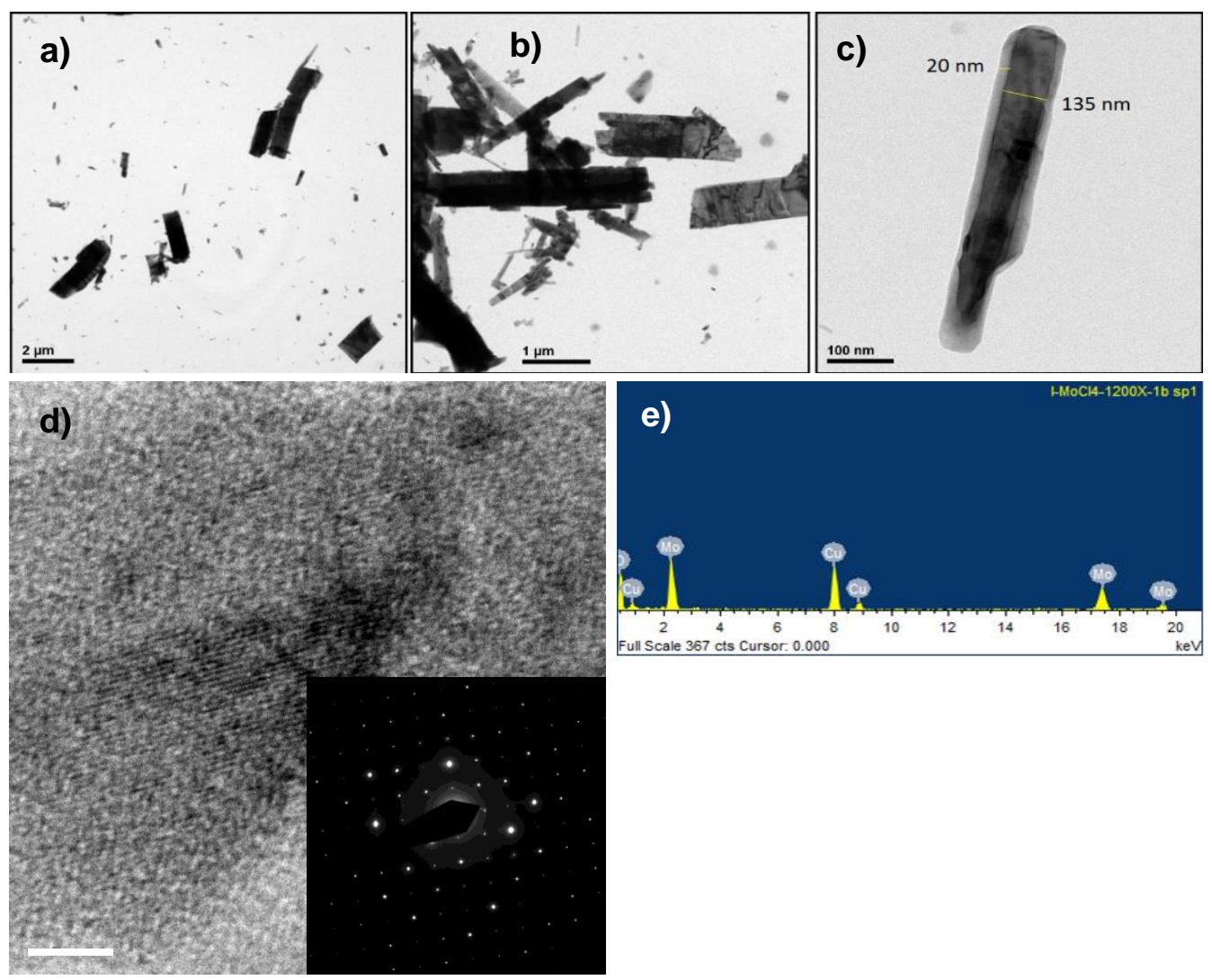

Figure 3. TEM a), b), c), SAE and HRTEM d) and EDS e) of $\mathrm{MoO}_{3}$ from the 1:1 Chitosan $\bullet \mathrm{MoCl}_{3}$ precursor.

For $\mathrm{WO}_{3}$ particles, as shown in figure 4, big agglomerates were observed. HRTEM images (figure 3d) confirmed the structure of $\mathrm{WO}_{3}$, as the interplanar distance of $0.37 \mathrm{~nm}(020)$ was measured in both images. EDS analysis see figure 4e, as expected confirms the presence of $\mathrm{W}$ and $\mathrm{O}$ elements. 


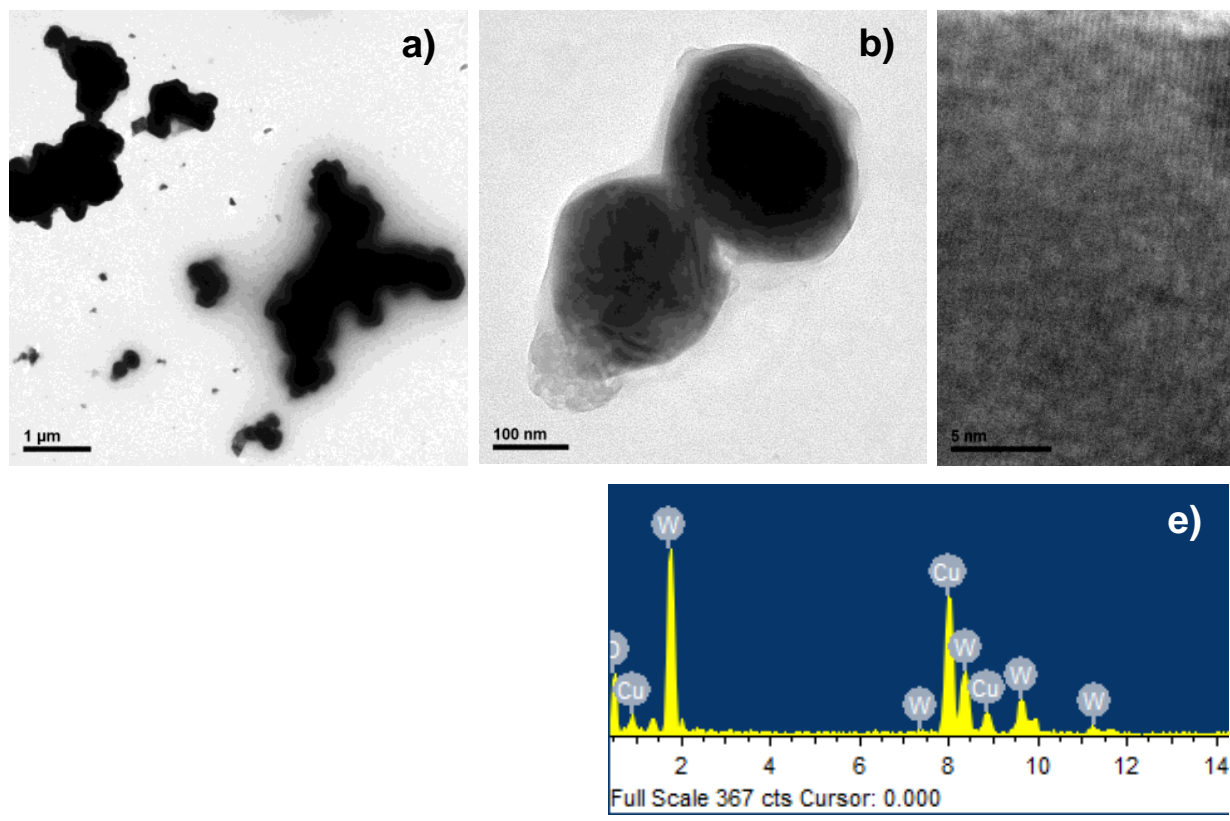

c)

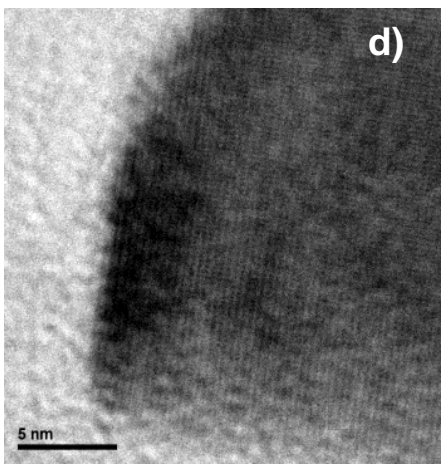

Figure 4. TEM a) and b) and $\mathrm{HRTEM}$ image c) d) and EDS e) of $\mathrm{WO}_{3}$ from PS-co-4-PVP•WCl $\mathrm{Wrecursors}_{4}$.

\section{Inclusion of $\mathrm{Cr}_{2} \mathrm{O}_{3}$ and $\mathrm{WO}_{3}$ inside silica}

Owing the most applications of nanostructured $\mathrm{Cr}_{2} \mathrm{O}_{3}$ and $\mathrm{WO}_{3}$ involves the use of these metal oxides inside $\mathrm{SiO}_{2}$ (for instance catalysis) we attempted the inclusion of $\mathrm{Cr}_{2} \mathrm{O}_{3}$ and $\mathrm{WO}_{3}$ inside silica using the here described solution-solid state method. $\mathrm{SiO}_{2}$ was generated by the sol-gel method and added over the solution were the precursor PS-co-4-PVP $\bullet$ MXn and Chitosan $\bullet$ MXn with $\mathrm{M}=\mathrm{Cr}$ and $\mathrm{W}$ was forming [71]. Then the PS-co-4-PVP•MXn//SiO ${ }_{2}$ and Chitosan $\bullet \mathrm{MXn} / / \mathrm{SiO}_{2}$ precursors were pyrolyzed forming the $\mathrm{Cr}_{2} \mathrm{O}_{3} / / \mathrm{SiO}_{2}$, $\mathrm{MoCl}_{3} / / \mathrm{SiO}_{3}$ and $\mathrm{WO}_{3} / / \mathrm{SiO}_{2}$ composites. The $\mathrm{X}$-ray analysis of the respective materials are shows in supplementary materials see figure $\mathrm{S} 4$.
The composite $\mathrm{Cr}_{2} \mathrm{O}_{3} / / \mathrm{SiO}_{2}$ and $\mathrm{WO}_{3} / / \mathrm{SiO}_{2}$ obtained both, from the Chitosan $\bullet$ $\mathrm{CrCl}_{3} / / \mathrm{SiO}_{2}$ as well as from PS-co-4-PVP $\bullet \mathrm{WCl}_{4} / / \mathrm{SiO}_{2}$ precursors exhibit the typical diffraction peaks of $\mathrm{Cr}_{2} \mathrm{O}_{3}$ or $\mathrm{WO}_{3}$ discussed already, as well as a broad peak between $2 \theta=15-20^{\circ}$ for the $\mathrm{Cr}_{2} \mathrm{O}_{3} / / \mathrm{SiO}_{2}$ composite and a broad peak between $2 \theta=5-20^{\circ}$ for the $\mathrm{WO}_{3} / / \mathrm{SiO}_{2}$ typical of amorphous silica [71-74].

The distribution of the metal oxides $\mathrm{Cr}_{2} \mathrm{O}_{3}$ and $\mathrm{WO}_{3}$ was investigated using the SEM-EDS mapping technique. For both composites $\mathrm{Cr}_{2} \mathrm{O}_{3} / / \mathrm{SiO}_{2}$ and $\mathrm{WO}_{3} / / \mathrm{SiO}_{2}$, a uniform distribution of the $\mathrm{Cr}_{2} \mathrm{O}_{3}$ and $\mathrm{WO}_{3}$ of the nanoparticles inside $\mathrm{SiO}_{2}$ was observed as is shows in figure $5 \mathrm{a}$ ) and $5 \mathrm{~b}$ ) and $6 \mathrm{a}$ ) and b).

\section{a)}

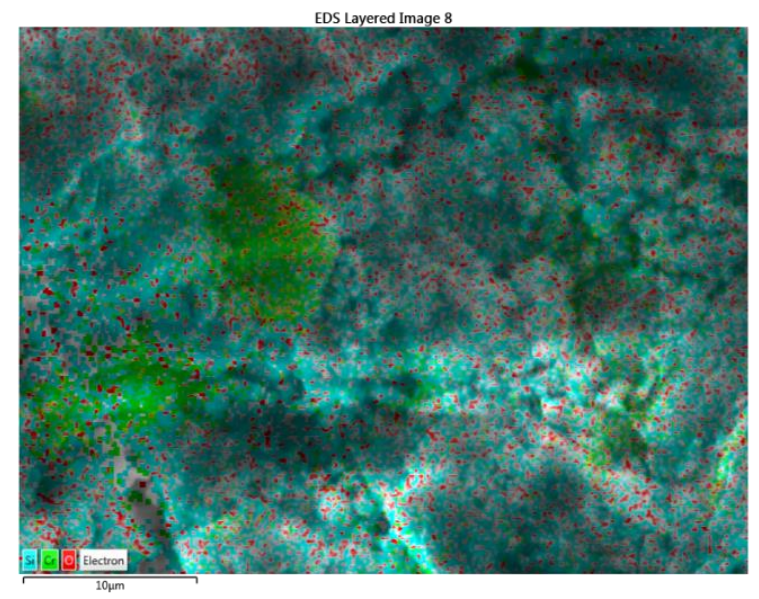

Si K $\alpha 1$

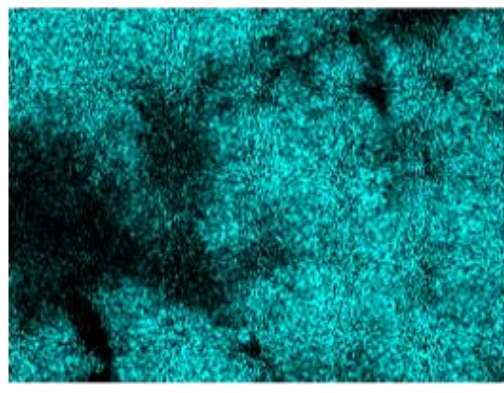

$10 \mu \mathrm{m}$
$\mathrm{O} K \alpha 1$

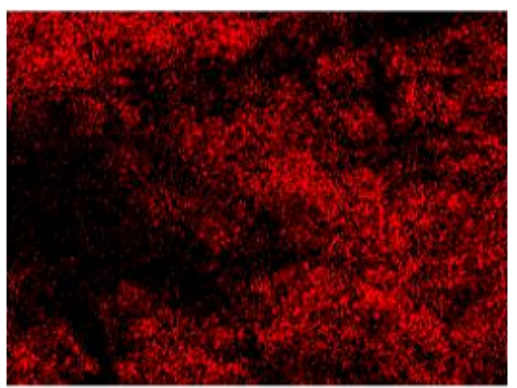

$10 \mu \mathrm{m}$
$\mathrm{Cr} \mathrm{K \alpha 1}$

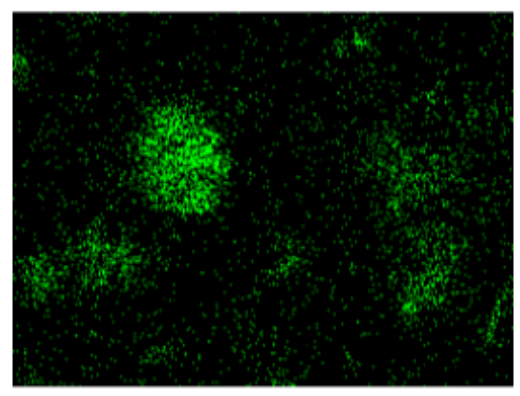

$10 \mu \mathrm{m}$ 
b)

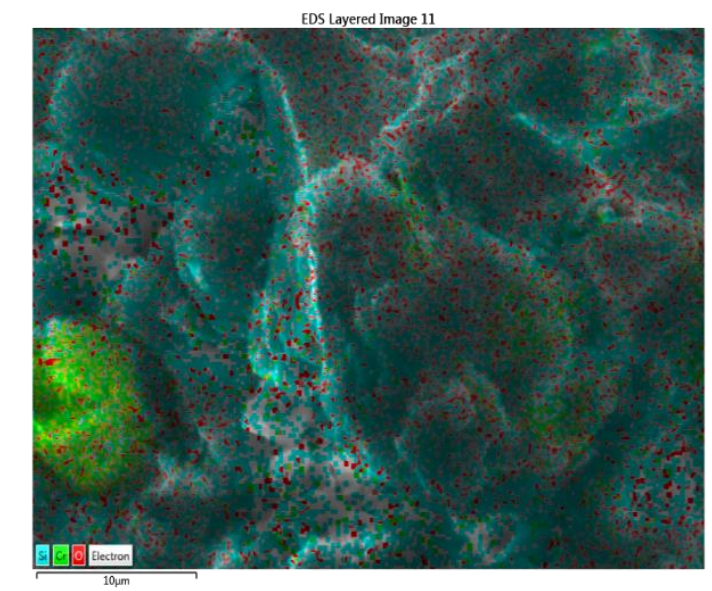

Si K $\alpha 1$

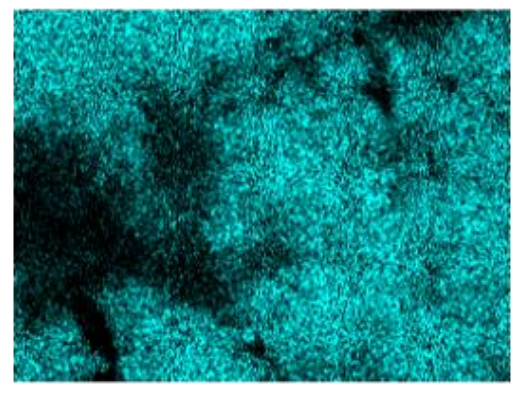

$10 \mu \mathrm{m}$
$\mathrm{O} K \alpha 1$

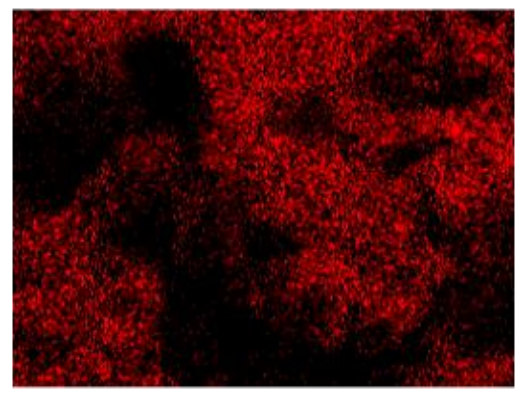

$\longdiv { 1 0 \mu \mathrm { m } }$
$\mathrm{Cr} \mathrm{K} \alpha 1$

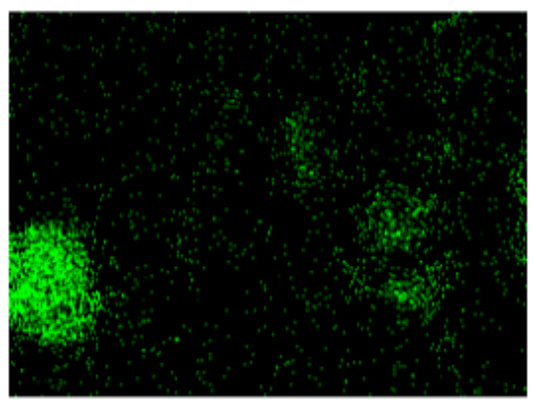

$10 \mu \mathrm{m}$

Figure 5. EDX-elemental mapping of a) $\mathrm{Cr}_{2} \mathrm{O}_{3}$ nanoparticles inside silica from PS-co-4-PVP• $\left(\mathrm{CrCl}_{3}\right)_{\mathrm{X}} / / \mathrm{SiO}_{2}$ precursor and of b) $\mathrm{Cr}_{2} \mathrm{O}_{3}$ nanoparticles inside silica from precursor Chitosan $\bullet\left(\mathrm{CrCl}_{3}\right)_{\mathrm{X}} / / \mathrm{SiO}_{2}$.

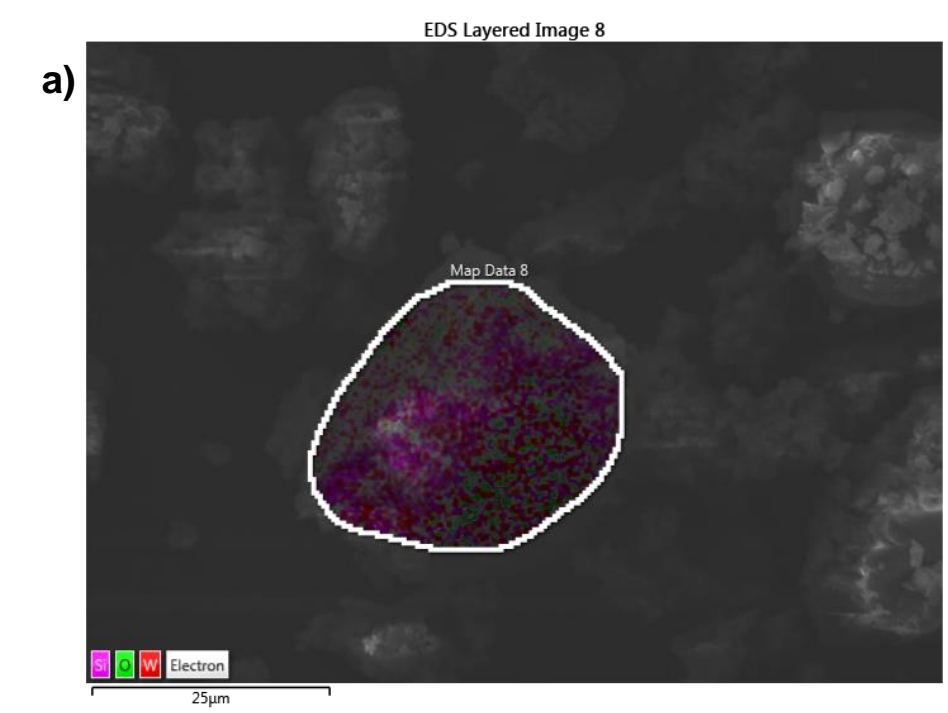

Si Ka1

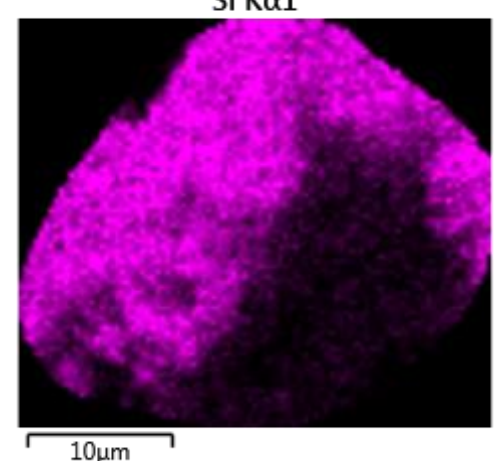

$\mathrm{O} K \alpha 1$

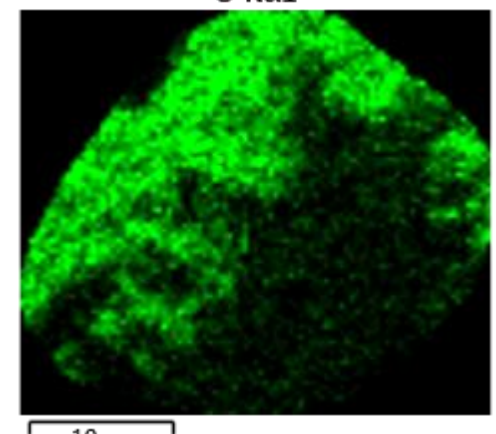

$10 \mu \mathrm{m}$
W L $\alpha 1$

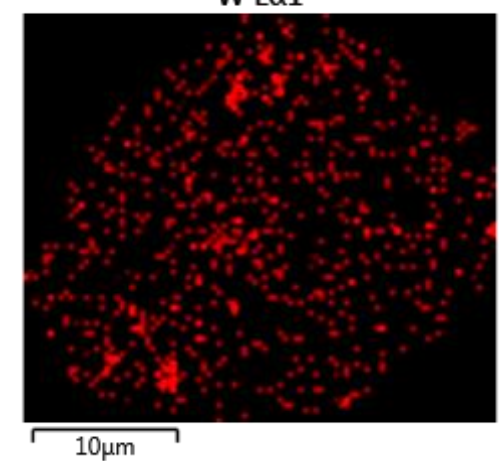


b)
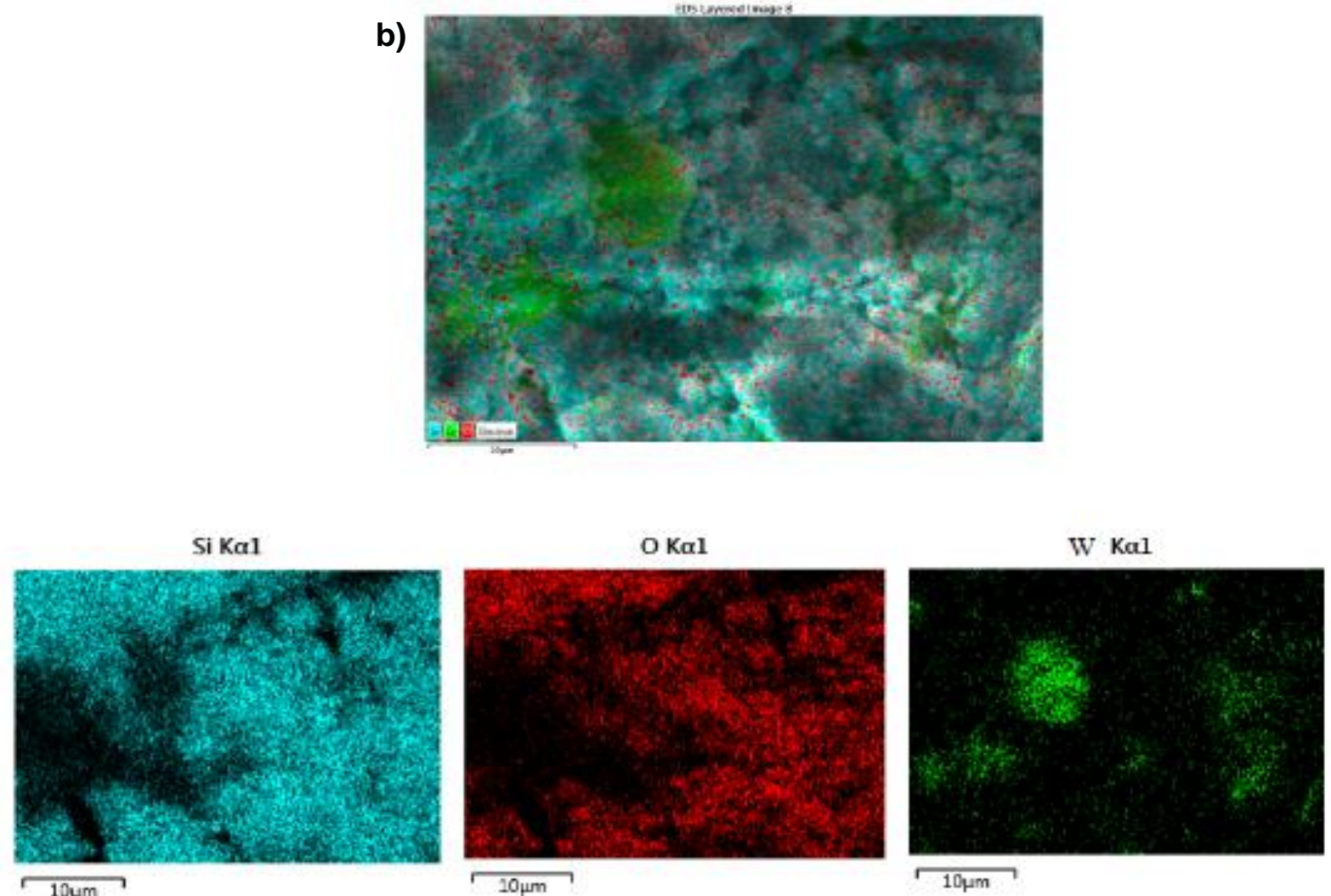

Figure 6. EDX-elemental mapping of a) $\mathrm{WO}_{3}$ nanoparticles inside silica from PS-co-4-PVP• $\left.\mathrm{WCl}_{4}\right)_{\mathrm{X}} / / \mathrm{SiO}_{2}$ precursor and of b) $\mathrm{WO}_{3}$ nanoparticles inside silica from precursor $\left(\right.$ Chitosan $\bullet\left(\mathrm{WCl}_{4}\right)_{\mathrm{X}} / / \mathrm{SiO}_{2}$.

\section{Formation Mechanism of the $\mathrm{Cr}_{2} \mathrm{O}_{3}, \mathrm{MoO}_{3}$ and $\mathrm{WO}_{3}$ nanoparticles.}

In order to give some insight about the formation mechanism of the nanostructured $\mathrm{Cr}_{2} \mathrm{O}_{3}, \mathrm{MoO}_{3}$ and $\mathrm{WO}_{3}$, we believe that materials from both precursors can be proposed using the mechanism of formation of nanostructured metallic materials from the oligomer precursor $\left\{\mathrm{NP}\left(\mathrm{OC}_{8} \mathrm{H}_{12}\right)_{2}\left(\mathrm{OC}_{6} \mathrm{H}_{4} \mathrm{PPh}_{2}\right.\right.$ $\left.\mathrm{Mn}(\mathrm{CO})_{2}\left(\eta^{5}-\mathrm{C}_{5} \mathrm{H}_{4} \mathrm{Me}\right)_{2}\right\}_{\mathrm{n}}[9,75]$. A schematic representation of this process is provided in figure 7 . Briefly, the first step on heating involves the formation of a 3D network to produce a thermally stable matrix. This step is crucial because it offsets the sublimation. The first heating step could involve a cross linking of the chitosan or PSP-4-PVP polymer giving a 3D matrix containing the $\mathrm{Cr}_{2} \mathrm{O}_{3}, \mathrm{MoO}_{3}$ and $\mathrm{WO}_{3}$, compounds linked to the polymeric chain.

The following steps could involve the starting of the organic carbonization, producing holes where the nanoparticles begin to nucleate. As it was confirmed in earlier studies $[9,75]$, the $\mathrm{Cr}_{2} \mathrm{O}_{3}, \mathrm{MoO}_{3}$ and $\mathrm{WO}_{3}$ could grow over layered graphitic carbon host which is lost near to the final annealing temperature ie. $800{ }^{\circ} \mathrm{C}$

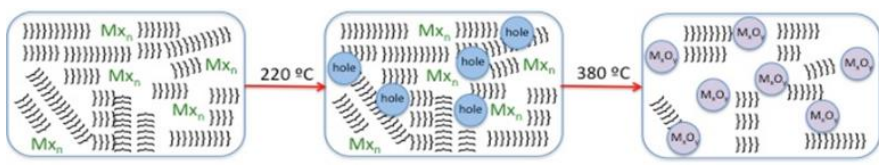

Figure. 7. Schematic representation of the proposed mechanism of formation of the metal oxide nanoparticles $\mathrm{M}_{\mathrm{x}} \mathrm{O}_{\mathrm{y}}=\mathrm{Cr}_{2} \mathrm{O}_{3}, \mathrm{MoO}_{3}$ and $\mathrm{WO}_{3} . \mathrm{MX}_{\mathrm{n}}$ represent the general formula of the metallic salt coordinated to the Chitosan or PSP-4PVP polymer and \} \} \} \} \} \} represent the respective polymeric. The temperature are referential general values.

\section{CONCLUSIONS}

The series of nanostructured $\mathrm{Cr}_{2} \mathrm{O}_{3}, \mathrm{MoO}_{3}$ and $\mathrm{WO}_{3}$ oxides can be in pure phase obtained from the solid-state method using as precursors the

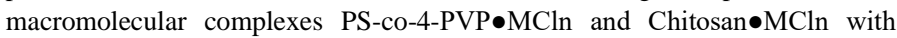
$\mathrm{M}=\mathrm{Cr}$, Mo and $\mathrm{W}$ by thermal treatment. Similarly, the composites $\mathrm{Cr}_{2} \mathrm{O}_{3} / / \mathrm{SiO}_{2}$, $\mathrm{MoCl}_{3} / / \mathrm{SiO}_{2}$ and $\mathrm{WO}_{3} / / \mathrm{SiO}_{2}$ were prepared from thermal treatment of the
PS-co-4-PVP•MCln $/ / \mathrm{SiO}_{2}$ and Chitosan $\bullet \mathrm{MCln} / / \mathrm{SiO}_{2}$. In these materials, the $\mathrm{Cr}_{2} \mathrm{O}_{3}, \mathrm{MoO}_{3}$ and $\mathrm{WO}_{3}$ oxides exhibited, in general, a uniform dispersion inside the silica matrix, which suggests a possible catalytic activity of these materials. The investigation of the optical properties of $\mathrm{Cr}_{2} \mathrm{O}_{3}, \mathrm{MoO}_{3}$ and $\mathrm{WO}_{3}$ and the effect on the inclusion inside the $\mathrm{SiO}_{2}$ are in course.

\section{ACKNOWLEDGEMENTS}

The authors acknowledge Fondecyt Projects 1160241, for financial support. Also thanks to Professor Antonio Laguna of the Institute of Nanoscience and Materials of Aragón (INMA), CSIC-University of Zaragoza, 50009 Zaragoza, Spain for the HRTEM measurements and analysis.

\section{COMPLIANCE WITH ETHICAL STANDARDS}

Competing interests, the authors declare that they have no competing interests.

\section{REFERENCES}

1.D.Worle, A.D. Pomaglio (2003). "Metal Complexes and Metals in Macromolecules" Wiley-VCH

2. C. Díaz and M.L. Valenzuela (2006) in Polymer Research Developments, "Coordination of Organometallic Fragments to Polyphospahzenes Containing Side Groups with Donor Atoms". R.K. Bregg Ed. Nova Science Publishers, New York Pp 1-22.

3. G.A. Carriedo, F.J. Garcia-Alonso, J.L. García Alvarez, C. Diaz, N. Yutronic (2002) Polyhedron 21, 2587-2592.

4.G.A. Carriedo, F.J. Garcia-Alonso, P. A. González, C. Diaz, N. Yutronic (2002) Polyhedron 21, 2579-2586.

5.C. Diaz, P. Castillo, G.A. Carriedo, P. Gomez-Elipe, F.J. Garcia-Alonso (2002). Macromolec. Phys. and Chem. 203, 1918-1925.

6. C. Díaz, M.L. Valenzuela (2006). Macromolecules 39, 103-111.

7.C. Díaz, M.L. Valenzuela (2006). Journal Inorganic and Organometallic Polymer and Materials 16, 419-435.

8. C. Díaz, M.L. Valenzuela, L. Zuñiga, C. O’Dwyer (2009). Journal Inorganic and Organometallic Polymer and Materials. 19, 507- 520.

9. C Díaz, M.L. Valenzuela, V. Lavayen, C. O’Dwyer (2012). Inorganic Chem. 51, 6228-6236. 
10. C. Zhang, J. Chen, Y. Zeng, X. Rui, J. Zhu, W. Zhang, Ch.Xu, T.M. Lim, H.H.Hng, Q. Yan (2012). Nanoscale 4, 3718-3724.

11. P. Poizot, L.S. Grugeon, L. Dupont, J-M Tarascon (2000). Nature 407, 496499.

12. Y. Li, A. Somorjai (2010). Nano.Lett. 10, 289-2295.

13. F. Bozon-Verduraz, F. Fievet, J.Y. Piquemal, R. Brayner, K. Kabouss, Y. Soumare, G. Viau, G. Shaffev (2009). Braz. J. Phys. 134-140.

14. A. Tricoli, M. Righettoni, A. Teleki (2010) Angew. Chem. Int. Ed. 49, 76327659.

15. P. Kamat (2012). J. Phy.Chem. C 116, 11849-11851.

16. H. Huang, B. Liang, X, Wang, D. Chen, G. Shen (2012). Journal of Material Chemistry 22, 13428- 13445.

17. J.S. Hu, L.S. Zhong, W.G. Song, L.J. Wan (2008). Adv. Mater. 20, 2977 2982.

18. Ch. Yan, D. Xue (2006). J. Phys. Chem. B 110, 1581-1586.

19. N. Pinna, M. Niederberger (2008). Angew. Chem. Int.Ed. 47, 5292-5304.

20. M. Fernandez-Garcia, A. Martinez-Arias, J.C. Hanson, J.A. Rodriguez (2004). Chem.Rev. 104, 4063-4104.

21. M.L. Khan, A. Glaria, C. Pages, M. Monge, L.S. Macary, A. Maisonnat, B. Chaudret (2009). J. Mat. Chem. 19, 4044-4060.

22. J.P. Jolivet, S. Cassignon, C. Chanea, D. Chiche, D. Durupthy, D. Portehault, (2010). C.R Chimie 13, 40-51.

23. C. Díaz, M.L. Valenzuela (2010) in Encyclopedia of Nanoscience and Nanotechnology, "Metallic Nanostructures Using Oligo and Polyphosphazenes as Template or Stabilizer in Solid State" H.S Nalwa Ed., American Scientific Publishers 16, 239-256.

24. A. Orlov, A. Roy, M. Lehmann, M. Driess and S. Polarz (2007). J. Am. Chem. Soc. 129, 371-375.

25. G. Walkers, I.P. Parkin (2009). J. Mater. Chem. 19, 574-590.

26. M. Meilikhov, K. Yusenko, D. Esken, S.A. Turner, G. Van Tendolo, R.A. Fischer (2010). Eur. J. Inorg. Chem. 3701-3714.

27. B. Teo, X. Sun (2007). Chem. Rev. 107, 1454-1532.

28. G.B. Khomutov, V.V. Kislov, M.N. Antipirina, R.V. Gainutdinov, S.P. Gubin, A.Y Obydenov, S.A. Pavlov, A.A. Rakhnyanskaya, A.N. SergeevCherenkov, E.S. Soldatov, D.B. Suyatin, A.L. Toltikhina, A. S. Trifonov, T.V. Yurova (2003). Microelectronic Engineering 69, 373-383.

29. K. Lee, W.S.Seo, Park (2003). J. Am. Chem. Soc. 125, 3408-3409.

30. S. U. Son, Y.Jang, K.Y. Yoon, Ch. An, Y. Hwang, J-G.Park, Han-Jin Noh, Jae-Young Kim, Jae-Hoon Park, T. Hyeon (2005). Chem Comm. 86-88.

31. D. Parvis, E.M.Kazemeini, A.M. Rashidi, Kh. Josan (2010). J. Nanopart. Res. 12, 1509-1521.

32. S.M. El-Sheikh, R.M. Mohamed, A.O. Fouad (2009). J. Alloys Comp. 482, 302-307. 33. M. Aghaie-Khafri, M.H. Kakaei (2012). Powder Technology 222, 152-160.

34. D. Chen, M. Liu, L. Yin, T. Li, Z. Yang, X. Li, B. Fan, H. Wang, R. Zhang, Z. Li, H. Xu, H. Lu, D. Yang, J. Sun, L. Gao (2011). J. Mater. Chem. 21, 9332-9342.

35. H.M. Martínez, J. Torres, L.D. López-Carreño, M.E. Rodríguez-García (2013). Materials Characterization 75, $184-193$.

36. X. Huang, H. Liu, X. Zhang, H. Jiang (2015). ACS Appl. Mater. Interfaces 7, $27845-27852$

37. R. Huirache-Acuñaa, F. Paraguay-Delgadoc, M.A. Albiterd, J. LaraRomerod, R. Martínez-Sánchezc (2009). Materials Characterization 60, 932 $-937$

38. C. Díaz, P. Castillo, M. L. Valenzuela (2005). Journal of Cluster Science 16, 515-522.

39. K. Desai, K. Kit, J. Jiajie, S. Zivanovic (2008). Biomacromolecules 9, 10001006.

40. Q. Li, E.T. Dunn, E.W. Grandmaison, M.F.A. Goosen (1992). J. Bioactive and Compatible Polymers 7, 370-397.

41. I. Aranaz, M. Mengibar, R. Harris, I. Paños, B.Miralles, N.Acosta, G. Galed and A. Heras (2009). Current Chemical Biology 3, 203-230.

42. R.B. Hernandez, O. Reyes, A.L. R. Merce (2007). J. Braz. Chem.Soc. 18, 1388-1396.

43. I.S. Lima, C. Airoldi (2004). Thermochim. Acta 421, 133-139.

44. E. Taboada, G. Cabrera, G. Cardenas (2003). J. Chil. Chem. Soc. 48 ,

45. K. Ogawa, K. Oka (1993). Chem. Mater. 5, 726-728.

46. S. Schlick (1986). Macromolecules 19, 192-195.

47. J. Brugnerotto, J. Lizardi, F.M. Goycoolea, W.Arguelles-Monal, J. Desbrieres, M. Rinaudo (2001). Polymer 42, 3569-3580.

48. H. Huang, X. Yang (2004). Carbohydrate Research 339, 2627-2631.

49. Y. Ding, X.H. Xia and C. Zhang (2006). Nanotechnology 17, 4156-4162.

50. M. Adlim, M.A. Bakar, K. Kong Live, J. Ismail (2004). J. Mol. Cat. 212, 141-149.

51. K. Okitsu, Y. Mizukoshi, T. A. Yamamoto, Y. Maeda and Y. Nagata (2007). Mater. Lett. 61, 3429-3431.
52. K.H. Yang, Y.Ch. Liu, T.Ch. Hsu, H.I. Tsai (2010). Mater.Research Bulletin 45, 63-68.

53. I. Zhitomirsky, A. Hashambhoy (2007). J. Mater. Proc. Tech. 191, 68-72.

54. H. Huang, Q. Yuan, X. Yang (2004). Colloids and Surfaces B: Biointerfaces 39, 31-37.

55. Y.Ch. Chang, D.H. Chen (2005). Journal of Colloid and Interfaces Science 283, 446-451.

56. L. Ding, Ch. Hao, Y. Xue, H. Ju (2007). Biomacromolecules 8, 1341-1346.

57. Y. Du, X.L. Luo, J.J. Xu, H. Y. Chen (2007). Bioelectrochemistry 70, 342 347.

58. X.L. Luo, J.J. Xu, Q. Zhang, G.J. Yang and H.Y.Chen (2005). Biosensors and Bioelectronics 21, 190-196.

59. E. Guibal (2005). Prog. Polym. Sci. 30, 71-109.

60. B. Geng, Z.Jin, T. Li and X. Qi (2009). Sci. Total Environ. 407, 4994-5000.

61. P. Guo, W. Wenyan, G. Liang, P. Yao (2008). J. Colloid Interface Sci. 323, 229-234.

62. L. A. Belfiore, M. P. Curdie and E. Ueda (1993). Macromolecules 26, 69086919.

63. A. Haynes, P. M. Maitlis, R. Quyoum, C. Pulling, H. Adams, S. E. Spey, R.W. Strange (2002). J. Chem. Soc. Dalton Trans. 2565-2572.

64. C. V. Franco, M. M. da SilvaPaula, G. Goulart, L. F. De Lima, L. K. Noda, N. S. Gonçalves (2006). Mater. Lett. 60, 2549-2553.

65. F. Wen, W. Zhang, G. Wei, Y. Wang, J. Zhang, M. Zhang, L. Shi (2008). Chem. Mater. 20, 2144-2150.

66. S. Klingelfer, W. Heitz, A. Greiner, S. Oestreich, S. Forster, M. Antoinietti (1997). J. Am. Chem. Soc. 119, 10116-10120.

67. P. Zheng, X. Jiang, X. Zhang, L. Shi (2006). Langmuir 22, 9393-2396.

68. C. Diaz, M.L. Valenzuela, G. Carriedo N. Yutronic (2014). J. Chil. Chem. Soc. 59, 2437-2441.

69. C. Díaz, V. Lavayen, C. O’D wyer (2010). J. Solid St. Chem 183, 1595-1603.

70. C. Díaz, M.L. Valenzuela, N. V. Lavayen, K. Mendoza, O. Peña, C. O’Dwyer (2011). Inorg. Chim. Acta. 377, 5-13.

71. C. Díaz, M.L. Valenzuela, M. Segovia, R. De la Campa, A. Presa-Soto (2018). J. Clust. Sci. 29, 251-266.

72. G. Yang, H. Yang, X. Zhang, K. lqbal, F. Feng, J. Ma, J. Qin, F. Yuan, Y. Cai, J. Ma (2020). Journal of Hazardous Materials 397, 122654.

73. D. Li, G. Wu, G. Gao, J. Shen, F. Huang (2011). ACS Appl. Mater. Interfaces 3, 4573-4579.

74. M.V. Borysenko, V.M. Bogatyrov, E.N. Poddenezhny, A. A. Boiko, A.A. Chuiko (2004). Journal of Sol-Gel Science and Technology 32, 327-331.

75. C. Díaz, M.L. Valenzuela, M.A. Laguna-Bercero, A. Orera, D. Bobadilla, S. Abarca, O. Peña (2017). RSC Advances 7, 27729-27736 